\title{
Morphology and viability of pollen grains from passion fruit species (Passiflora spp.)
}

Taliane Leila Soares ${ }^{1}$, Onildo Nunes de Jesus ${ }^{1}$, Everton Hilo de Souza ${ }^{2}$, Janay Almeida dos Santos-Serejo ${ }^{1}$ and Eder Jorge de Oliveira ${ }^{1,3}$

Received: 8 April, 2013. Accepted: 1 August, 2013

\begin{abstract}
The characterization and viability of pollen grains are useful tools to guide crosses in breeding programs. The objective of this study was to describe the morphological patterns and viability of pollen grains from five accessions of Passiflora edulis f. flavicarpa O. Deg. and five accessions of Passiflora setacea DC. Pollen morphology descriptions were made using light microscopy and scanning electron microscopy, whereas the viability analysis was performed by in vitro germination and histochemical analysis (Lugol's solution and 2,3,5-triphenyltetrazolium chloride). Pollen grains assessed for germination were inoculated in culture medium containing $\mathrm{Ca}\left(\mathrm{NO}_{3}\right) \cdot 4 \mathrm{H}_{2} \mathrm{O}(0.03 \%), \mathrm{Mg}\left(\mathrm{SO}_{4}\right) .7 \mathrm{H}_{2} \mathrm{O}$ $(0.02 \%), \mathrm{KNO}_{3}(0.01 \%), \mathrm{H}_{3} \mathrm{BO}_{3}(0.01 \%)$, sucrose (15\%) and agar $(0.8 \%)$. Although P. edulis and P. setacea showed the same shape and type of pollen aperture, the two differed in terms of their morphology and exine ornamentation pattern. In vitro analysis showed that one of the P. edulis f. flavicarpa accessions (designated BGP 330) presented the highest germination rate $(53.98 \%)$ and longest pollen tube $(2.18 \mathrm{~mm})$. The histochemical analysis overestimated pollen viability when compared with the in vitro results. The results of this study contribute to the breeding of Passiflora species by increasing the understanding of their morphology and pollen grain viability.
\end{abstract}

Key words: in vitro germination, histochemistry, scanning electron microscopy, Passifloraceae, pollen tube

\section{Introduction}

Passiflora is the largest of the Passifloraceae genera, with approximately 530 different species (Feuillet \& MacDougal 2007). The genus is rich in inter-specific and intra-specific variability, a large number of its species being native to Brazil (Bernacci et al. 2005). Many species are used for their medicinal properties and due to their edible fruit (Sousa \& Meletti 1997). In addition, many of these species are appreciated on a global basis for their ornamental properties, their seeds being widely sold and marketed, mainly in North America and Europe (Ulmer \& MacDougal 2004).

The enhanced process of collecting and conserving Passiflora germplasm is an important phase in the formation of germplasm seed banks, although it is still being necessary to invest heavily in research involving stored genetic variations, especially in wild species. These species have huge potential for ornamental cultivation due to the aesthetic attributes of their flowers and leaves, as well as the sheer quantity of flowers they produce (Abreu et al. 2009). In this respect, extraction of these genetic resources makes for better understanding of the biological and genetic aspects of these species, for subsequent inclusion in genetic improvement programmes.
Despite the variety of economic uses and the potential of Passiflora as ornamental plants in other countries, such usage is practically non-existent in Brazil. The Passion Fruit Germplasm Bank, maintained by Embrapa Mandioca e Fruticultura (Embrapa Cassava and Fruits), has many different species that could be used for ornamental purposes, among these being the species Passiflora Setacea DC., of high agronomic importance due to its near immunity to foliar viruses and diseases under field conditions (Junqueira et al. 2005; Braga et al. 2006). By means of pre-breeding programmes, this species has become an excellent alternative for the transference of resistance genes to the yellow passion fruit (P. edulis f. flavicarpa), i.e., the species of greatest economic importance within the Passiflora genus.

Studies into pollen viability and morphology are of high importance in relation to genetic breeding programmes, aimed at attaining potentially promising selections. Pollen viability is a male fertility measure widely used in the monitoring of stored pollen, aimed at ensuring fertility and achieving cross-fertilization between genotypes flowering during different periods (Oliveira et al. 2001). Determination of pollen viability can occur through the use of direct methods such as the inducement of in vitro germination

\footnotetext{
${ }^{1}$ Embrapa Mandioca e Fruticultura, Cruz das Almas, BA, Brazil

${ }^{2}$ Universidade de São Paulo, Centro de Energia Nuclear na Agricultura, Piracicaba, SP, Brazil

${ }^{3}$ Author for correspondence: eder.oliveira@embrapa.br
} 
(Acar \& Kakani 2010; Alcaraz et al. 2011; Sorkheh et al. 2011) and in vivo germination (Fakhim et al. 2011) or other, indirect methods based on cytological parameters, such as pollen staining (Beyhan \& Serdar 2008; Abdelgadir et al. 2012). However, in vitro germination of pollen is the most utilised method for viability testing and for genetic breeding programmes (Satish \& Ravikumar 2010).

The study of pollen grains from the species within the Passifloraceae family, principally those belonging to the Passiflora genus, has aroused the interest of various palynologists. First observations on the morphology of Passifloraceae pollen grains were initially recorded by Mohl (1834) and Fritzsche (1837). Presting (1965) conducted a comprehensive and detailed study on Passifloraceae pollen grains, covering 153 species within this particular family, distributed across 13 genera, outlining the apertural system and proposing a specific family phylogeny based on pollen characteristics.

Very few further studies on Passifloraceae pollen grains have been carried out since Presting's 1965 publication. Among those that have been published are studies by Milward-de-Azevedo et al. (2010), including a pollen analysis of 21 Passiflora taxa, subgenus Decaloba; Barrios et al. (2005), involving a description of 121 species of Passiflora and two species of Dilkea Mast., in addition to the application of pollen morphology in relation to the new Passiflora infrageneric classification. Recently, Evaldt et al. (2011) detailed and compared a series of obtained pollen morphotypes with those available in literature, for 15 species of Passiflora. Despite the existence of studies dealing with pollen morphology and the viability of species within the Passiflora genus, to date there is still very little information on Passiflora setacea, one of the most widespread wild species throughout Brazil and with vast potential for a number of different uses.

This work has therefore been carried out with the objective of examining the pollen morphology of $P$. edulis f. flavicarpa (yellow passion fruit) in comparison with $P$. setacea DC (sururuca passion fruit), as well as evaluating the viability of their respective pollen grains for the purposes of subsidising the genetic breeding programmes for this particular family.

\section{Material and methods}

Pollen grains were collected during the anthesis period of five accessions of $P$. edulis $\mathrm{f}$. flavicarpa (designated BGP 222, BGP 330, BGP 337, BGP 340 and BGP 341), and five accessions of $P$. setacea (BGP 237, BGP 238, BGP 240, BGP 242 and BGP 272) from the Passion Fruit Germplasm Bank stored at Embrapa Mandioca e Fruticultura, located in the city of Cruz das Almas, in the State of Bahia, Brazil.

For morphological analysis purposes, the pollen grains were fixed in a modified Karnovsky solution (Karnovsky 1965) [glutaraldehyde (2\%), paraformaldehyde (2\%), $\mathrm{CaCl}_{2}$
$(0.001 \mathrm{M})$, sodium cacodylate buffer solution $(0.05 \mathrm{M})$ ], in a pH 7.2 solution for $48 \mathrm{~h}$, dehydrated in a graded ethanol series. The samples were dried out in hexamethyldisilazane, afterwards being mounted on metallic supports (stubs) and then sputter coated with gold for 180 seconds. Images were stored using a variable pressure scanning electron microscope (LEO 435 VP; Carl Zeiss, Jena, Germany).

The pollen grains were acetolysed through a weak lactic acetolysis (ACLAC 40) process in accordance with the methodology described by Raynal \& Raynal (1979), with the polar diameter and equatorial diameter being measured for 25 pollen grains from an equatorial view. In relation to size, the pollen grains were classified in accordance with Hesse et al. (2009). The definition of the shape of the pollen grains was determined by the polar diameter/equatorial diameter ratio in accordance with the classification proposed by Erdtman (1952).

The pollen grains that were acetolysed and prepared for examination under optical microscope were also digitally photographed using a light microscope (DM1000; Leica Microsystems, Wetzlar, Germany) connected to a video camera (Sony, Tokyo, Japan) and a personal computer, making use of Image-Pro Plus Software, version 3.0 for Windows (Media Cybernetics, Inc., Bethesda, MD, USA). Adopted terminology, including pollen descriptions, are organised in accordance with criteria proposed by Punt et al. (2007) and Hesse et al. (2009), the definition of Presting (1965) being used for the general description of pollen apertures.

The pollen grains were inoculated on Petri dishes containing a culture medium of $15 \%$ sucrose, $0.01 \%$ boric acid, $0.01 \%$ potassium nitrate, $0.03 \%$ calcium nitrate and $0.02 \%$ magnesium sulphate, then solidified with $0.8 \%$ agar (Merck'), with pH adjusted to 7.0 and autoclaved at $121^{\circ} \mathrm{C}$ for $20 \mathrm{~min}$. The choice of this particular method was based on preliminary in vitro germination studies of Passiflora species (data not presented).

Using a brush, we evenly distributed the pollen over the culture medium in order to achieve the most homogenous distribution of the material possible. A sample consisting of the pollen from five flowers of each genotype was distributed among the dishes. After inoculation, the dishes were maintained in the dark at controlled temperature conditions $\left(27 \pm 1^{\circ} \mathrm{C}\right)$ before proceeding with the counting process of the germinated grains of pollen and measurement of the pollen tube length. These processes took place $24 \mathrm{~h}$ after inoculation, within the culture medium, by means of observation through a binocular stereomicroscope at $10 \times$ magnification.

The experimental design for in vitro pollen germination was completely randomised, using a total of 10 accessions and eight experiments; each of those experiments being represented on a Petri dish. All of the grains in the dish were counted for the purposes of calculating germination percentages, whereas, in order to calculate pollen tube length, five tubes were randomly measured in each of the Petri dishes, totalling forty pollen tubes for each of the studied 
genotypes. Pollen grains were considered germinated when the size of their respective pollen tubes were found to be equal to, or greater than, the diameter of the pollen itself.

Pollen viability was assessed through histochemical analysis using 2\% Lugol's solution and a 2,3,5-triphenyltetrazolium chloride (TTC) solution of $1 \%$, diluted in a $50 \%$ sucrose solution. The TTC denotes the presence of active dehydrogenase enzymes (Beyhan \& Serdar 2008), whereas Lugol's solution denotes the presence of starch (Ge et al. 2011; Hasnunnahar et al. 2012).

A pollen sample taken from five anther accessions was laid out on a glass slide, followed by the addition of a drop of a specific staining material, and then covered with another glass slide. Slide scanning with the aid of an optical microscope took place for the purposes of obtaining a randomly stained pollen sample, of which 100 pollen grains/ slide/genotype were counted, each of these having three repetitions, reaching a total of 300 pollen grains for each stained sample. The experimental design was completely randomized using a $10 \times 2$ factorial design (accessions $\times$ stained samples), each of these in triplicate.

For statistical analysis purposes, the germination percentage and viability data of the pollen grains was submitted to arcsine square root transformation $\mathrm{x} / 100$ (Sorkheh \& Amini 2010). The pollen grains were then submitted to ANOVA using the $\mathrm{F}$ test, in which measurements were compared by means of the Scott-Knott test $(\mathrm{p}<0.05)$. Analysis was carried out using the SAS Program (SAS 2010).

\section{Results}

The morphometric data used for determining the shape and size of the Passiflora edulis f. flavicarpa and P. setacea pollen grains is displayed in Tab. 1 and illustrated in Figs. 1 and 2. The palynological analysis for the studied Passifloraceae species, through use of an optical microscope, revealed the presence of large size pollen grains, varying in size from $44.50 \mu \mathrm{m}$ to $75.00 \mu \mathrm{m}$. The pollen grains from the P. edulis f. flavicarpa and P. setacea species are isopolar and oblate spheroidal.

Generally speaking, pollen grain measurements taken from an equatorial view were identified as having greater polar and equatorial diameters of the pollen grains were greater for Passiflora edulis f. flavicarpa than for P. setacea. In terms of the type of aperture, the pollen grains of both analysed species are 6-syncolpate (Figs. 1 and 2).

Based on the results of scanning electronic microscope analysis, the pollen grains from Passiflora edulis f. flavicarpa and $P$. setacea were found to be very similar, principally in terms of colpi ornamentation and colpi length, sub-circular scope, longitudinal joining at the tips, and the forming of a ring around the pseudo-operculum (Figs. 1 and 2). The exine is heteroreticulate, with columellate, sinuous simple muri and exposed columella (Fig. 1 c, g, k, o, s and Fig. 2 c, g, k, o, s).

For both species, the presence of bacula of varying heights was discovered inside the lumen. All of the Passiflora setacea (Fig. 2) accessions and three of the P. edulis f. flavicarpa accessions (BGP 330, BGP 337 and BGP 340) had large sized lumens with many bacula inside (Fig. $1 \mathrm{~g}, \mathrm{k}, \mathrm{o}$ ). The other $P$. edulis f. flavicarpa accessions (BGP 222 and BGP 341) also had large lumens, but with few internal bacula (Fig. $1 \mathrm{c}, \mathrm{s}$ ).

The BGP 242 accession (Passiflora setacea), when scanned with an electron microscope, revealed the presence of germinal papilla (Fig. 2 b) corresponding to the edge of the pollen tube but still within the grain itself, initiating its own phase of germination. In terms of the BGP 330 (P. edulis f. flavicarpa) a certain quantity of lipophilic substances (pollenkitt) were observed between the columellae of the pollen grain reticule. There was an in vitro analysis effect $(\mathrm{p}<0.001)$ between the studied accessions in relation to germination and the length of the pollen tube. The largest germination and length percentage values in relation to the pollen tube were observed for the BGP 330 (Passiflora edulis f. flavicarpa)

Table 1. Morphometric and morphological characteristics of Passiflora edulis f. flavicarpa O. Deg. and Passiflora setacea DC. pollen grains $(\mathrm{n}=25)$.

\begin{tabular}{|c|c|c|c|c|c|c|c|c|c|}
\hline \multirow{2}{*}{ Accession } & \multirow{2}{*}{ Species } & \multicolumn{2}{|c|}{$\mathrm{PD}$} & \multicolumn{2}{|c|}{$\mathrm{ED}$} & \multirow{2}{*}{$\mathrm{PD} / \mathrm{ED}$} & \multirow{2}{*}{ Shape } & \multirow{2}{*}{ Size } & \multirow{2}{*}{ Aperture } \\
\hline & & Range & $x \pm s_{x}$ & Range & $x \pm s_{x}$ & & & & \\
\hline BGP 222 & P. edulis $\mathrm{f}$. flavicarpa & $74.0-72.0$ & $73.3 \pm 0.5$ & $74.8-73.2$ & $74.0 \pm 0.4$ & 0.99 & oblate spheroidal & large & 6-syncolpate \\
\hline BGP 330 & P. edulis $\mathrm{f}$. flavicarpa & $75.0-73.5$ & $74.4 \pm 0.3$ & $75.8-74.1$ & $75.0 \pm 0.4$ & 0.99 & oblate spheroidal & large & 6-syncolpate \\
\hline BGP 337 & P. edulis $\mathrm{f}$. flavicarpa & $69.8-68.1$ & $68.9 \pm 0.4$ & $71.0-70.0$ & $70.5 \pm 0.2$ & 0.98 & oblate spheroidal & large & 6-syncolpate \\
\hline BGP 340 & P. edulis $\mathrm{f}$. flavicarpa & $73.2-70.3$ & $71.7 \pm 0.8$ & $73.6-72.0$ & $72.4 \pm 0.3$ & 0.99 & oblate spheroidal & large & 6-syncolpate \\
\hline BGP 341 & P. edulis f. flavicarpa & $73.0-70.0$ & $71.4 \pm 0.9$ & $73.9-72.0$ & $73.1 \pm 0.4$ & 0.98 & oblate spheroidal & large & 6-syncolpate \\
\hline BGP 237 & P. setacea & $51.6-45.9$ & $48.7 \pm 1.2$ & $55.4-48.8$ & $52.6 \pm 1.5$ & 0.93 & oblate spheroidal & large & 6-syncolpate \\
\hline BGP 238 & P. setacea & $54.4-45.5$ & $49.0 \pm 1.6$ & $60.4-49.8$ & $54.8 \pm 1.9$ & 0.90 & oblate spheroidal & large & 6-syncolpate \\
\hline BGP 240 & P. setacea & $51.6-41.7$ & $47.2 \pm 2.0$ & $54.0-48.5$ & $51.6 \pm 1.2$ & 0.95 & oblate spheroidal & large & 6-syncolpate \\
\hline BGP 242 & P. setacea & $52.9-45.0$ & $48.9 \pm 1.5$ & $58.4-51.0$ & $54.6 \pm 1.3$ & 0.90 & oblate spheroidal & large & 6-syncolpate \\
\hline BGP 272 & P. setacea & $53.3-44.5$ & $47.8 \pm 1.9$ & $58.0-48.0$ & $52.5 \pm 1.9$ & 0.91 & oblate spheroidal & large & 6-syncolpate \\
\hline
\end{tabular}

$\mathrm{PD}$ - Polar diameter; $\mathrm{ED}$ - equatorial diameter; $\mathrm{x}$ - mean; $\mathrm{s}_{\mathrm{x}}$ - standard deviation from the mean. 

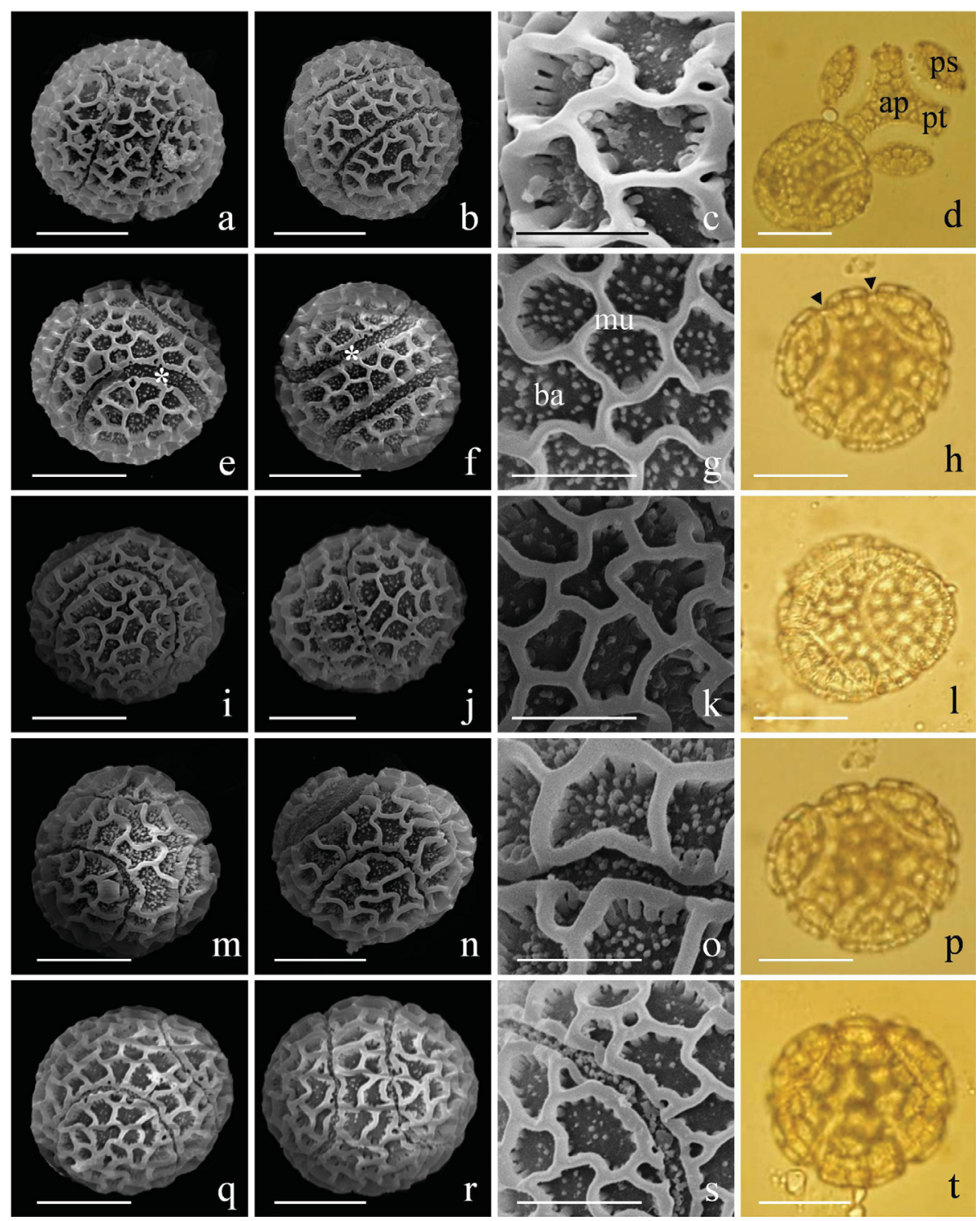

Figure 1. Pollen grains of Passiflora edulis f. flavicarpa O. Deg using a scanning electron microscope (SEM) and a light microscope (LM). a-d) BGP 222. e-h) BGP 330. i-l) BGP 337. m-p) BGP 340. q-t) BGP 341. a, b, e, f, i, j, m, n, q, r) SEM overview. c, g, k, o, s) Details of the exine and colpi using a SEM. d, h, l, p, t) LM overview. ap: apocolpus; ba: bacula; mu: muri; ps: pseudoperculum; pt: pontoperculum; arrowhead: apertures; ${ }^{*}$ fusion of the apertures within the apocolpus. Bars: a, b, d, e, f, h, i, j, l, m, n, p, q, r, t $=20 \mu \mathrm{m} ; \mathrm{c}, \mathrm{g}, \mathrm{k}, \mathrm{o}, \mathrm{s}=10 \mu \mathrm{m}$.

genotype, with respective values of $53.98 \%$ and $2.18 \mathrm{~mm}$ (Tab. 2, Fig. 3a). However, the BGP 237 (P. setacea) accession presented a low germination index (3.10\%), as illustrated in Fig. 3b. The smallest pollen tube lengths were registered in five accessions (BGP 237, BGP 238, BGP 240, BGP 242 and BGP 272) from the same group (Tab. 2). In terms of pollen variability observed through histochemical analysis, differences $(\mathrm{p}<0.001)$ were noted between the accessions, stained samples and accession and the stained sample interactions (Tab. 2).

The Lugol's solution viability analysis indicated the presence of starch, varying from $63.67 \%$ to $98.20 \%$ between the BGP 222 accession (Passiflora edulis f. flavicarpa) and the BGP 242 accession (P. setacea), of which had been stained brown (Tab. 2, Fig. 3c). The BGP 330 (P. edulis f. flavicarpa) and BGP 242 (P. setacea) accessions once again had the highest pollen viability percentages in relation to both stained samples. The pollen grains considered to be non-viable in the presence of Lugol's solution were identified by the absence of staining and by the size of the pollen, which was smaller in relation to the viable pollen grains (Fig. 3c). However, the test using the TTC staining solution revealed the presence of active dehydrogenase enzymes with an amplitude variation of 57.00-87.87\% between accession BGP 340 (P. edulis f. flavicarpa) and accession BGP 242 (P. setacea), by means of staining the pollen grains red (Tab. 2, Fig. 3d). The non-TTC stained pollen grains have 

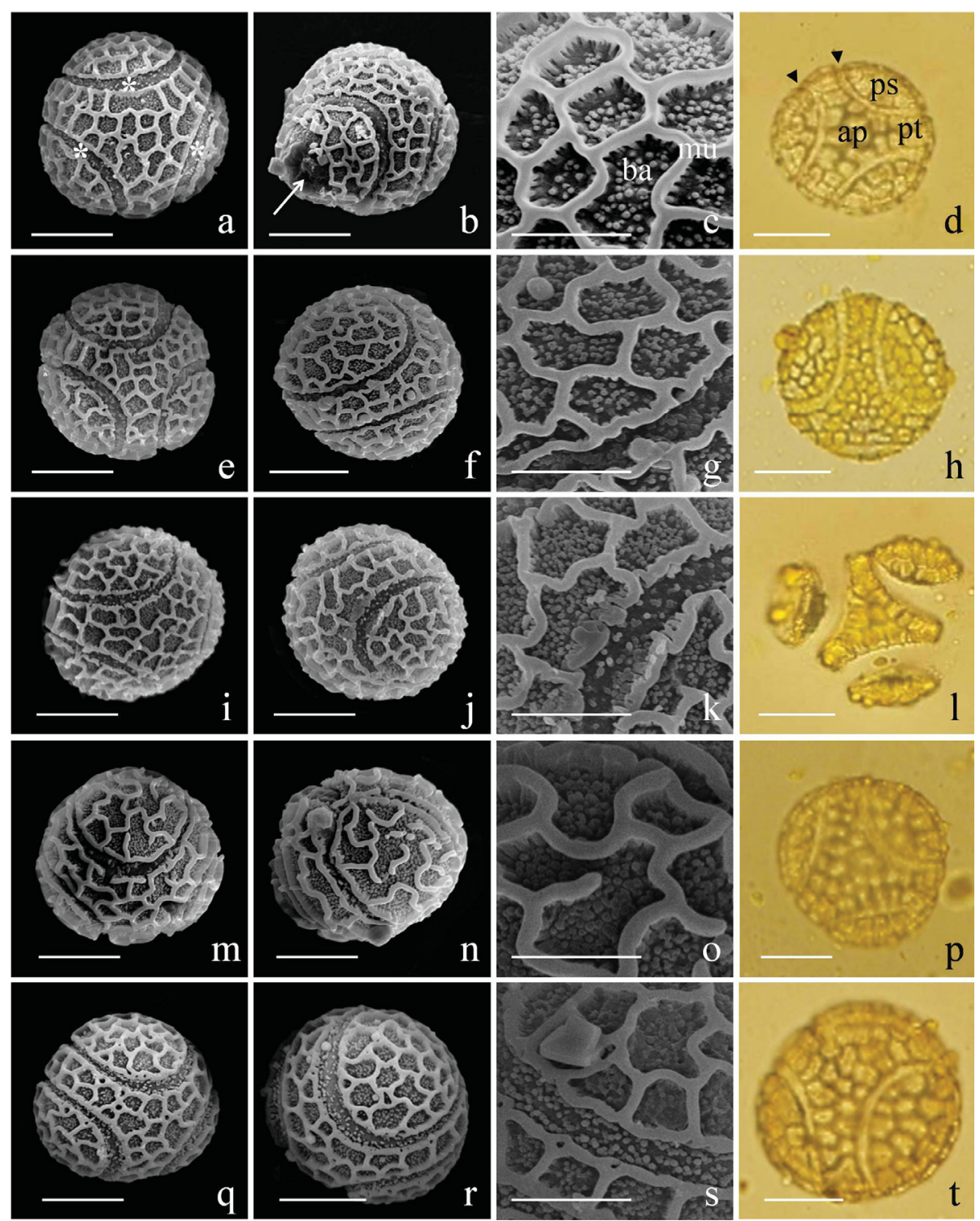

Figure 2. Pollen grains of Passiflora setacea DC., using a scanning electron microscope (SEM) and a light microscope (LM). a-d) BGP 237. e-h) BGP 238. i-l) BGP 240. m-p) BGP 242. q-t) BGP 272. a, b, e, f, i, j, m, n, q, r) SEM overview. c, g, k, o, s) Details of the exine and colpi using a SEM. d, h, l, p, t) LM overview. ap: apocolpus; ba: bacula; mu: muri; ps: pseudoperculum; pt: pontoperculum; arrowhead: apertures; arrow: germinal papilla; asterisk: fusion of the apertures within the apocolpus. Bars: a, b, d, e, f, h, i, j, l, m, n, p, q, r, t $=20 \mu \mathrm{m} ; \mathrm{c}, \mathrm{g}, \mathrm{k}, \mathrm{o}, \mathrm{s}=10 \mu \mathrm{m}$.

Table 2. In vitro germination percentages, length of the pollen tube, and test of pollen viability in Passiflora edulis f. flavicarpa O. Deg. and P. setacea DC accessions. *

\begin{tabular}{|c|c|c|c|c|c|}
\hline \multirow{2}{*}{ Accession } & \multirow{2}{*}{ Species } & \multirow{2}{*}{ Germination (\%) } & \multirow{2}{*}{ Length of the pollen tube $(\mathrm{mm})$} & \multicolumn{2}{|c|}{ Pollen viability } \\
\hline & & & & Lugol's & TTC \\
\hline BGP 222 & P. edulis f. flavicarpa & $30.10 \mathrm{c}$ & $1.38 \mathrm{c}$ & $63.67 \mathrm{dA}$ & $54.67 \mathrm{~dB}$ \\
\hline BGP 330 & P. edulis f. flavicarpa & $53.98 \mathrm{a}$ & $2.18 \mathrm{a}$ & 97.26 aA & $81.33 \mathrm{bB}$ \\
\hline BGP 337 & P. edulis f. flavicarpa & $27.35 \mathrm{c}$ & $1.76 \mathrm{~b}$ & $83.00 \mathrm{bA}$ & $76.00 \mathrm{bB}$ \\
\hline BGP 340 & P. edulis f. flavicarpa & $37.74 \mathrm{~b}$ & $1.33 \mathrm{c}$ & $78.67 \mathrm{cA}$ & $57.00 \mathrm{~dB}$ \\
\hline BGP 341 & P. edulis $\mathrm{f}$. flavicarpa & $42.36 \mathrm{~b}$ & $1.70 \mathrm{~b}$ & $85.00 \mathrm{bA}$ & $77.33 \mathrm{bB}$ \\
\hline BGP 237 & P. setacea & $3.10 \mathrm{~g}$ & $0.73 \mathrm{~d}$ & $88.10 \mathrm{bA}$ & $64.57 \mathrm{cB}$ \\
\hline BGP 238 & P. setacea & $6.14 \mathrm{f}$ & $0.59 \mathrm{~d}$ & $86.37 \mathrm{bA}$ & $67.53 \mathrm{cB}$ \\
\hline BGP 240 & P. setacea & $18.92 \mathrm{~d}$ & $0.62 \mathrm{~d}$ & $90.47 \mathrm{bA}$ & $75.77 \mathrm{bB}$ \\
\hline BGP 242 & P. setacea & $40.44 \mathrm{~b}$ & $0.86 \mathrm{~d}$ & $98.20 \mathrm{aA}$ & $87.87 \mathrm{aB}$ \\
\hline BGP 272 & P. setacea & $14.19 \mathrm{e}$ & $0.77 \mathrm{~d}$ & $91.37 \mathrm{bA}$ & $76.40 \mathrm{bB}$ \\
\hline
\end{tabular}

${ }^{*}$ Mean values followed by equal lowercase letters in the column and uppercase letters in the row do not differ in relation to the Scott-Knott test ( $\left.\mathrm{p}<0.001\right)$. 
a greyish colour (Fig. 3d). Please note that the majority of pollen grains that had an estimated level of pollen viability through use of the TTC method, revealed certain quantities of lipophilic substances next to the exine, in the form of large drops classified as pollenkitt (Fig. 3 e-f).

\section{Discussion}

The complexity of the pollen grains from the Passifloraceae species in relation to their number and type of apertural has resulted in various diagnostics being found in existing literature. An example of this is the classification of Passiflora edulis pollen grains in relation to the type of aperture, having been cited as being 6-colporoidate (Presting 1965), 3-zonoporate (Desai \& Thorne 1974), geminicolpate (Spirlet 1965), 6-colpate (Dettke \& Santos 2009) and 6-syncolpate (Evaldt et al. 2011). These variations were not observed in the material analysed during this particular project. The five $P$. edulis f. flavicarpa accessions that were evaluated corroborate with the results obtained by Evaldt et al. (2011) in relation to the number and type of apertures.

Apertures are very important morphological characters in relation to the identification of pollen grains. According to Moore \& Webb (1979), the apertures are the first characteristics used when identifying variations of pollen grains or spore fossils. In addition to the aperture, there are other important characters which can be applied to pollen mor- phology, for identification, definition of shape and other factors such as wall ornamentation. In terms of Passiflora, studies made by Dettke \& Santos (2009) underscore the importance of the number and type of apertures as part of taxonomic and phylogenetic studies, in terms of such a diverse genus from a palynological point of view.

The pollen grains taken from the Passiflora species analysed as part of this study indicated the presence of pseudopercula and a pontoperculum. According to Presting (1965), the term pseudoperculum is used to describe ornate structures resulting from the concrescent growth of pairs of colpi. The pseudoperculum not only has the appearance of an operculum but, according to the author, additionally functions as an operculum during the germination of pollen grains on the stigma, which frequently detaches itself during palynological preparations (Fig. $1 \mathrm{~d}$ and Fig. $2 \mathrm{l}$ ). This fact was verified for both analysed species, indicating that there is something hitherto unknown that causes structures to detach themselves from the remaining sporodermis. A number of authors have pointed out that within the Passiflora genus, the species belonging to the Decaloba subgenus is tolerant to the acetolysis technique, whereas species of the Passiflora subgenus have pollen grains that are extremely sensitive and rupture easily, making it difficult to view them with an optical microscope (Araújo \& Santos 2004; Evaldt et al. 2011).

In terms of the exine surface of the pollen grains, the presence of a large quantity of lipophilic substances was

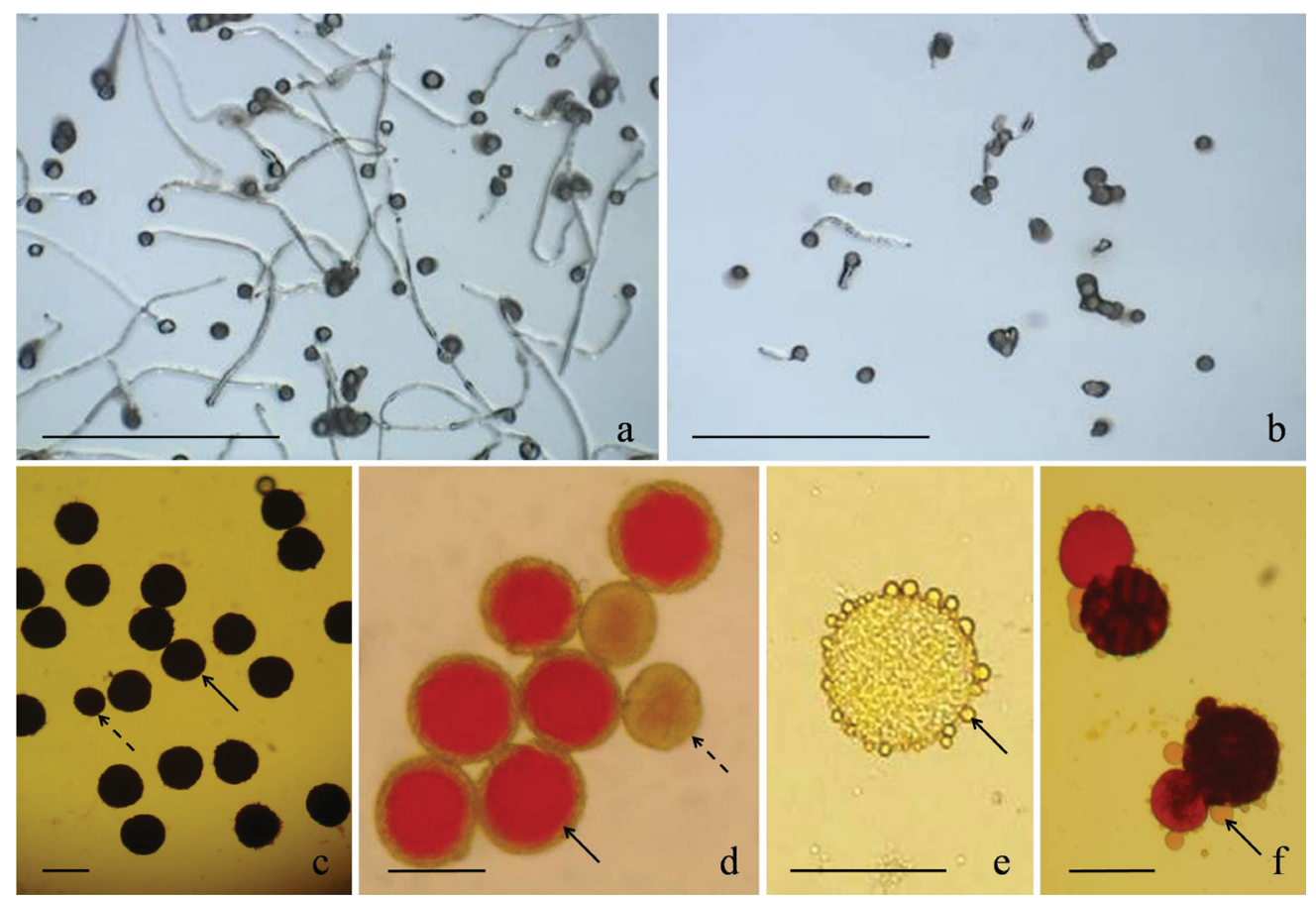

Figure 3. a) High germination percentage of the pollen grains and the length of the pollen tube of Passiflora edulis f. flavicarpa (BGP 330). Low germination percentage in P. setacea (BGP 237). c) Pollen grains of $P$. edulis f. flavicarpa (BGP 330) stained with Lugol's solution, viable (full arrow) and non-viable (dotted arrow). d) Pollen grains of P. edulis f. flavicarpa (BGP 330) after staining with TTC, viable (full arrow) and non-viable (dotted arrow). e) Acetolysed pollen grain with traces of pollenkitt (full arrow) in P. edulis f. flavicarpa (BGP 330). f) Pollen stained with TTC, showing traces of pollenkitt (full arrow) in P. edulis f. flavicarpa (BGP 330). Bars: $\mathrm{d}-\mathrm{e}=1000 \mu \mathrm{m} ; \mathrm{f}-\mathrm{i}=200 \mu \mathrm{m}$. 
observed, associated with the exine in the form of large droplets or a fibrillar appearance between the reticule detached columella (Fig. 3 e, f). These lipophilic substances, known as pollenkitt, were also observed by Souza et al. (2004) in yellow passion fruit. Pollenkitt occurs in widely angiosperms and the majority of entomophilous species, as well as having an important purpose during the dispersion of pollen grains, existing as part of the system for recognition of pollen grains on the stigma, adhesion of grains to the stigma and the attraction of pollinators due to the colouring and volatilization of compounds, among other factors (Nepi \& Franchi 2000; Piffanelli et al. 1998; Pacini \& Hesse 2005). Lersten (2004) reports direct evidence that pollenkitt and tryphine, substances originating from exudation of the tapetum, could be types of recognition factors responsible for the germination of compatible pollen or the rejection of incompatible pollen within the stigma. Despite Passiflora edulis f. flavicarpa and P. setacea pollen grains having the same type of pollen apertures, these species actually differ in a number of more specific palynological aspects, such as ornamentation of the exine, the quantity of bacula inserted into the lumen, and the diameter of the pollen grains. In vitro germination is a technique that simulates in vivo conditions, aimed at investigating the ability of a pollen grain to emit a pollen tube and undergo fertilization. Generally speaking, the majority of pollen germination and pollen tube development was observed in Passiflora edulis f. flavicarpa when compared with P. setacea. Cruz et al. (2008) obtained almost $100 \%$ pollen grain germination in P. edulis; these being statistics which are significantly higher than those obtained throughout the present study. The differences found between in vitro pollen viability studies in relation to the yellow passion fruit are probably due to the genetic origin of the material itself, environmental conditions and the culture mediums used for germination. Kakani et al. (2005) confirms that the differences observed during in vitro pollen germination and the growth of the pollen tube in relation to twelve cotton cultivars (Gossypium hirsutum) were, in fact, related to variations in the cultivars themselves. Similarly, Franzon et al. (2005) working with feijoa (Acca sellowiana (Berg) Burret) reported differences between species and between cultivars within the same species, in relation to the necessary culture medium conditions for in vitro pollen germination.

In vitro germination, although providing a controlled experimental system, does not completely reproduce in vivo pollen tube growth, with interactions occurring between culture medium composition and different types of different vegetable materials. However, according to Soares et al. (2008), the in vitro germination technique produces results that can approximate the growth that occurs during in vivo germination, thus demonstrating the importance of having well suited conditions for each species being studied.

The fact is, histochemical treatments result in different viability responses, as expected, since each test is carried out on an individual pollen grain component. When comparing the two histochemical tests (Lugol's solution and TTC), it is worth noting that pollen viability in TTC was consistently less for all of the analysed passion fruit accessions, in comparison with that obtained in Lugol's solution. This can probably be explained by the fact that intact pollen grains and those with viable chromosomes could have a reduced level of viability due to low pollen grain enzyme activity, due to the TTC having an effect on the active dehydrogenase and peroxidase enzymes, as well as possible connections with cellular respiration (Stanley \& Linskens 1974; Kearns \& Inouye 1993).

There is evidence that the staining method overestimates pollen germination percentages, whereas the in vitro test underestimates them (Galletta 1983). According to Scorza \& Sherman (1995), reactions to staining materials may not correlate well with in vitro pollen germination or with fertilisation abilities. The results obtained in the present study are in agreement with that statement, given that our pollen germination data indicated a significantly lower rate than that observed when using staining materials. Similarly, when analysing pollen viability for guava genotypes (Psidium guajava), in which estimations had been made for in vitro pollen germination and staining method germination (Lugol's solution and acetic orcein), Coser et al. (2012) observed that the results obtained through the use of staining materials were better than those when using in vitro methods. These authors state that the use of staining materials, while extremely attractive due to their simplicity and ease of use, overestimate guava pollen viability when compared with results obtained in vitro. However, a number of authors acknowledge that histochemical analysis with the use of staining materials for certain species could produce false-positive results when compared with in vitro germination testing (Stone et al. 1995; Dafni et al. 2005). For example, Parfitt \& Ganeshan (1989) reported that there was no significant correlation between in vitro pollen germination and that of the TTC staining test, in relation to Prunus species. Munhoz et al. (2008), compared five types of staining materials during pollen viability testing of Carica papaya L. and noted that only the TTC method correlated positively with the percent pollen germination for that particular species. However, when comparing five staining materials, Abdelgadir et al. (2012) noted that only the TTC method was capable of differentiating between viable and non-viable pollen grains, concluding that TTC staining was the most efficient method for assessing the viability of the pollen studied, which was that of Jatropha curcas L. (Euphorbiaceae).

Viability by means of the TTC method in the presence of saline solution, based on changes in tissue colouring, reduced by the dehydrogenase enzymes of the live tissues, results in a compound known as formazan (Beyhan \& Serdar 2008) of a carmine red colour. Various authors have argued that the TTC test is a reliable means of estimating pollen 
viability, because it produces results that are comparable to those of in vitro germination tests (Bolat \& Pirlak 1999; Huang et al. 2004). In addition, TTC is widely used because of its relatively simple and rapid application.

The results obtained in the present study contribute to the passion fruit genetic breeding programme. Our results also improve the understanding and facilitate the identification of the reproductive system of superior genotypes by evaluating the existing viability of pollen in the germplasm, for subsequent utilisation in controlled hybridizations.

The use of pollen morphotype characters, for taxonomic studies, is an alternative to the use of other characteristics, such as evaluating the colour of leaves and flowers or the size of certain structures which are more susceptible to changes than are pollen grain characteristics, which are considered to be better preserved (Benzing 2000). Morphometric and morphologic analyses demonstrate that the two types of analysed species, despite having the same shape and the same type of pollen aperture, actually differ in terms of more specific palynological attributes, specifically in relation to exine ornamentation, the quantity of bacula inserted into the lumen and the diameter of the pollen itself; information that assists in palynological and taxonomy studies into the Passiflora genus.

\section{Acknowledgements}

This study received financial support from the Brazilian Conselho Nacional de Desenvolvimento Científico e Tecnológico (CNPq, National Council for Scientific and Technological Development), the Fundação de Amparo à Pesquisa do Estado da Bahia (FAPESB, Foundation for Research Support of the State of Bahia) and the Brazilian Coordenação de Aperfeiçoamento de Pessoal de Nivel Superior (CAPES, Coordination for Enhancement of Higher Education Personnel). The authors would like to thank the staff of the Núcleo de Apoio à Pesquisa em Microscopia Eletrônica Aplicada a Agricultura (NAP/MEPA, Centre for the Support of Electron Microscopy Research Applied to Agriculture) of the Escola Superior de Agricultura "Luiz de Queiroz" da Universidade de São Paulo (ESALQ-USP, University of São Paulo, Luiz de Queiroz Graduate School of Agriculture), for the use of the scanning electron microscope.

\section{References}

Abdelgadir, H.A.; Johnson, S.D. \& Van Staden, J. 2012. Pollen viability, pollen germination and pollen tube growth in the biofuel seed crop Jatropha curcas (Euphorbiaceae). South African Journal of Botany 79: $132-139$

Abreu, P.P.; Souza, M.M.; Santos, E.A.; Pires, M.V.; Pires, M.M. \& Almeida, A.F. 2009. Passion flower hybrids and their use in the ornamental plant market: perspectives for sustainable development with emphasis on Brazil. Euphytica 166: 307-315.

Acar, I. \& Kakani, V.G. 2010. The effects of temperature on in vitro pollen germination and pollen tube growth of Pistacia spp. Scientia Horticulturae 125: 569-572.
Alcaraz, M.L.; Montserrat, M. \& Hormaza, J.I. 2011. In vitro pollen germination in avocado (Persea americana Mill.): Optimization of the method and effect of temperature. Scientia Horticulturae 130: $152-156$.

Araújo, R.C.M. \& Santos, F.A.R. 2004. Palinologia de Espécies do Gênero Passiflora L (Passifloraceae) da Chapada Diamantina, Bahia, Brasil. Sitientibus Série Ciências Biológicas 4: 37-42.

Barrios, L.; Caetano, C.M.; Cardoso, C.I.; D’Eeckenbrugge, G.C.; Arroyave, J.A. \& Olaya, C.A. 2005. Caracterización del pollen de especies de los géneros Passiflora e Dilkea. Acta Agronómica 54: 19-23.

Benzing, D.H. 2000. Bromeliaceae: Profile an adaptive radiation. Cambridge, Cambridge University Press.

Bernacci, L.C.; Meletti, L.M.M.; Soares-Scott, M.D. \& Passos, I.R.S. 2005. Espécies de maracujá: caracterização e conservação da biodiversidade. Pp. 559-586. In: Faleiro, F.G.; Junqueira, N.T.V. \& Braga, M.F. (Eds.). Maracujá: germoplasma e melhoramento genético. Planaltina, Embrapa Cerrados.

Beyhan, N. \& Serdar, U. 2008. Assessment of pollen viability and germinability in some European chestnut genotypes (Castanea sativa L.). HortScience 35: 171-178.

Bolat, I. \& Pirlak, L. 1999. An investigation on pollen viability, germination and tube growth in some stone fruits. Journal of Agriculture and Forestry 23: 383-388.

Braga, M.F.; Santos, E.C.; Junqueira, N.T.V.; Sousa, A.A.T.C.; Faleiro, F.G.; Rezende, L.N. \& Junqueira, K.P. 2006. Enraizamento de estacas de três espécies silvestres de Passiflora. Revista Brasileira de Fruticultura 28: 284-288.

Coser, S.M.; Fontes, M.M.P. \& Ferreira M.F.S. 2012. Assessment of pollen viability in guava genotypes. Acta Horticulturae 959: 140-144.

Cruz, T.V.; Souza, M.M.; Roza, F.A.; Viana, A.J.C.; Belo, G.O. \& Fonseca, J.W.S. 2008. Germinação in vitro de grãos de pólen em Passiflora suberosa L. para sua utilização em hibridação interespecífica. Revista Brasileira de Fruticultura 30: 875-879.

Dafni, A.; Pacini, E. \& Nepi, M. 2005. Pollen and stigma biology. Pp. 83-142. In: Dafni, A.; Kevan, P.G. \& Husband, B.C. (Eds.). Practical Pollination Biology. Cambridge, Ontario, Enviroquest Ltd.

Desai, N.P. \& Thorne, S.G. 1974. Pollen grains of Passifora edulis Sims. and P. edulis Sims. f. flavicarpa Deg. Journal of Palynology 10: 145-148.

Dettke, G.A. \& Santos, R.P. 2009. Tipos de aberturas dos grãos de pólen de espécies de Passiflora L. (Passifloraceae). Acta Botanica Brasilica 23: 1119-1128.

Erdtman, G. 1952. Pollen morphology and plant taxonomy. Angiosperms. Stockholm, Almqvist e Wiksell.

Evaldt, A.C.P.; Bauermann, S.G.; Cancelli, R.R.; Acioli, M. \& Neves, P.C.P. 2011. Morfologia polínica de Passifloraceae Juss. ex Kunth. no Rio Grande do Sul, Brasil. Revista Brasileira de Biociência 9: 75-87.

Fakhim, R.S.H.; Hajilou, J. \& Zaare, N.F. 2011. Pollen germination and pistil performance in several Iranian peach cultivars. International Journal AgriScience 1: 71-77.

Feuillet, C. \& MacDougal, J.M. 2007. Passifloraceae. Pp. 270-281. In Kubitzki, K. (Ed.). The families and genera of vascular plants. Berlin, Springer.

Franzon, R.C.; Corrêa, E.R. \& Raseira, M.C.B. 2005. In vitro pollen germination of feijoa (Acca sellowiana (Berg) Burret). Crop Breeding and Applied Biotechnology 5: 229-233.

Fritzsche, J. 1837. Über den Pollen. Mem. Sav. Etrang. Acad. St. Petersburg.

Galletta, G.J. 1983. Pollen e seed management. Pp. 23-47. In: Moore, J.N. \& Janick, J. (Eds.). Methods in fruits breeding. Indiana, Purdue University Press.

Ge, Y.; Fu, C.; Bhandari, H.; Bouton, J.; Brummer, E.C. \& Wang, Z.Y. 2011. Pollen Viability and Longevity of Switchgrass (Panicum virgatum L.). Crop Science 51: 2698-2705.

Hasnunnahar, M.; Khan, M.M.R. \& Isshiki, S. 2012. Pollen and seed fertility of three functional male-sterile lines of eggplant with the wild Solanum cytoplasms. Scientia Horticulturae 139: 58-61.

Hesse, M.; Halbritter, H.; Zetter, R.; Weber, M.; Buchner, R.; Frosch-Radivo, A. \& Ulrich, S. 2009. Pollen terminology. An illustrated handbook. Vienna, Springer. 
Huang, Z.; Zhu, J.; Um, X. \& Lin, J. 2004. Pollen dispersion, pollen viability and pistil receptivity in Leymus chinensis. Annals of Botany 93: 295-301.

Junqueira, N.T.V.; Braga, M.F.; Faleiro, F.G.; Peixoto, J.R. \& Bernacci, L.C. 2005. Potencial de espécies silvestres de maracujazeiro como fonte de resistência a doenças. Pp.81-106. In: Faleiro, F.G.; Junqueira, N.T.V.; Braga, M.F. (Org.). Maracujá: germoplasma e melhoramento genético. Planaltina, Embrapa Cerrados.

Kakani, V.G.; Reddy, K.R.; Koti, S.; Wallace, T.P.; Prasad, P.V.V.; Reddy, V.R. \& Zhao, D. 2005. Differences in vitro pollen germination and pollen tube growth of cotton cultivars in response to high temperature. Annals of Botany 96: 59-67.

Karnovsky, M.J. 1965. A formaldehyde-glutaraldehyde fixative in high osmolality for use in electron microscopy. Journal of Cell Biology 27: 137-138.

Kearns, C.A. \& Inouye, D. 1993. Techniques for pollinations biologists. Niwot, Colorado, University press of Colorado.

Lersten, N.R. 2004. Flowering Plant Embryology, with emphasis on economic species. Oxford, Blackwell Publishing.

Milward-de-Azevedo, M.A.; Souza, F.C.; Baumgratz, J.F.A. \& GonçalvesEsteves, V. 2010. Palinotaxonomia de Passiflora L. subg. Decaloba (DC.) Rchb. (Passifloraceae) no Brasil. Acta Botanica Brasilica 24: 133-145.

Mohl, H. 1834. Beiträge zur Anatomie und Physiologie der Gewächse. Erstes Heft, Über den Bau und die Formen der Pollenkörner. Bern, Fischer.

Moore, P.D. \& Webb, J.A. 1978. An illustrated guide to pollen analysis. $1^{\text {a }}$ ed. New York, A Halsted Press Book.

Munhoz, M.; Luz, C.F.P.; Meissner Filho, P.E.; Barth, O.M. \& Reinert, F. 2008. Viabilidade polínica de Carica papaya L.: uma comparação metodológica. Revista Brasileira de Botânica 31: 209-214.

Nepi, M. \& Franchi, G.G. 2000. Cytochemistry of mature angiosperm pollen. Plant Systematics and Evolution 222: 45-62.

Oliveira, M.S.P.; Maués, M.M. \& Kalume, M.A.A. 2001. Teste de viabilidade de pólen in vivo e in vitro em genótipos de açaizeiro. Acta Botanica Brasilica 15: 27-33.

Pacini, E. \& Hesse, M. 2005. Pollenkitt - its composition, forms and functions. Flora 200: 399-415.

Parfitt, D.E \& Ganeshan, S. 1989. Comparison of procedures for estimating viability of Prunus pollen. Hortscience 24: 354-356.

Piffanelli, P.; Ross, J.H.E. \& Murphy, D.J. 1998. Biogenesis and functions of the lipidic structures of pollen grains. Sexual Plant Reproduction 11: $65-80$.
Presting, D. 1965. Zur morphologie der Pollenkorner der Passifloraceen. Pollen et Spores 7: 193-247.

Punt, W.; Hoen, P.P.; Blackmore, S.; Nilsson, S. \& Le Thomas, A. 2007. Glossary of pollen and spore terminology. Review of Palaeobotany and Palynology 143: 1-81.

Raynal, A. \& Raynal, J. 1979. Une technique de préparation des grains de pollen fragiles. Adansonia 2: 77-79.

SAS Institute Inc. 2010. Sas/Stat user's guide: statistics, Version 9.1.3 ed. SAS Institute, Cary. NC. USA.

Satish, D. \& Ravikumar, R.L. 2010. Standardization of in vitro pollen germination media in selected varieties of cotton and tomato. Karnataka Journal of Agricultural Sciences 23: 317-319.

Scorza, R. \& Sherman, W.B. 1995. Peaches. Pp. 325-440. In: Janik, J. \& Moore, J.N. (Eds.). Fruit breeding. New York, John e Sons.

Soares, T.L.; Silva, S.O.; Costa, M.A.P.C.; Santos-Serejo, J.A.; Souza, A.S.; Lino, L.S.M.; Souza, E.H. \& Jesus, O.N. 2008. In vitro germination and viability of pollen grains of banana diploids. Crop Breeding Applied Biotechnology 8: 111-118.

Sorkheh, K. \& Amini, F. 2010. Principle and procedures of multivariate statistical analysis. Tehran. Daneshparvar Press.

Sorkheh, K.; Shiran, B.; Rouhi, V.; Khodambashi, M.; Wolukau, J.N. \& Ercisli, S. 2011. Response of in vitro pollen germination and pollen tube growth of almond (Prunus dulcis Mill.) to temperature, polyamines and polyamine synthesis inhibitor. Biochemical Systematics and Ecology 39: 749-757.

Sousa, J.S.I. \& Meletti, L.M.M. 1997. Maracujá: espécies, variedades e cultivos. Piracicaba, Fealq.

Souza, M.M.; Pereira, T.N.S.; Viana, A.P.; Silva, L.C. \& Sudré, C.P. 2004. Pollen viability and fertility in wild and cultivated Passiflora species (Passifloraceae). Beitrage zur Biologie der Pflanzen 73: 1-18.

Spirlet, M.L. 1965. Utilization taxonomique des grains de pollen de Passifloracees. Pollen et Spores 7: 249-301.

Stanley, R.G. \& Linskens, H.F. 1974. Pollen biochemistry management. Berlin, Springer Verlag.

Stone, J.L.; Thomson, J.D. \& Dent-Acosta, S.J. 1995. Assessment of pollen viability in hand-pollination experiments: a review. American Journal Botany 82: 1186-1197.

Ulmer, T. \& MacDougal, J.M. 2004. Passiflora: passionflowers of the world. Portland, Timber Press. 